\title{
Advances in morphometrics in archaeobotany
}

Article

Accepted Version

Portillo, M., Ball, T. B., Wallace, M., Murphy, C., Pérez-Díaz, S., Ruiz-Alonso, M., Aceituno, F. J. and López-Sáez, J. A. (2020) Advances in morphometrics in archaeobotany.

Environmental Archaeology: the Journal of Human Palaeoecology, 25 (2). pp. 246-256. ISSN 1749-6314 doi: https://doi.org/10.1080/14614103.2019.1569351 Available at https://centaur.reading.ac.uk/81875/

It is advisable to refer to the publisher's version if you intend to cite from the work. See Guidance on citing.

To link to this article DOI: http://dx.doi.org/10.1080/14614103.2019.1569351

Publisher: Taylor \& Francis

All outputs in CentAUR are protected by Intellectual Property Rights law, including copyright law. Copyright and IPR is retained by the creators or other copyright holders. Terms and conditions for use of this material are defined in the End User Agreement.

\section{www.reading.ac.uk/centaur}

\section{CentAUR}


Central Archive at the University of Reading

Reading's research outputs online 


\title{
Advances in Morphometrics in Archaeobotany
}

Marta Portillo ${ }^{1}$, Terry B. Ball ${ }^{2}$, Michael Wallace ${ }^{3}$, Charlene Murphy ${ }^{4}$, Sebastián Pérez-Díaz ${ }^{5}$, Mónica Ruiz-Alonso ${ }^{5}$, Francisco Javier Aceituno ${ }^{6}$, José Antonio López-Sáez ${ }^{5}$

${ }^{1}$ University of Reading, Department of Archaeology, Reading, UK

${ }^{2}$ Brigham Young University, Department of Ancient Scripture, Provo, USA

${ }^{3}$ University of Sheffield, Department of Archaeology, Sheffield, UK

${ }^{4}$ University College London, Institute of Archaeology, London, UK

${ }^{5}$ CSIC, Institute of History, Madrid, Spain

${ }^{6}$ University of Antioquia, Department of Anthropology, Medellín, Colombia

\begin{abstract}
Morphometric analysis offers an alternative or augmentation to traditional archaeobotanical methods to address differences within and between plant species and their remains, refining and enhancing taxonomic resolution. Morphometrics, the measurement of size and shape, and the multivariate statistical analysis of generated quantitative variables, have long played a major role in biological research, including plant taxonomy and systematics, although its application in archaeobotany is relatively recent. Over the last few decades there has been an increasing interest in the use of morphometrics for analysing a varied range of archaeological plant materials (mainly seeds, pollen, phytoliths, and starch grains). In particular, morphometrics have contributed to the study of the domestication and spread of many cereals world-wide, as well as that of other taxa including legumes, underground storage organs (USO), and fruits (such as olives, grapes, and dates). This paper reviews current methodologies, recent applications, and advances in the use of morphometrics in archaeobotanical research, discusses its role in exploring major research questions, and suggests possible future directions for its use.
\end{abstract}

\section{Keywords:}

Morphometry, computer-assisted image analysis, archaeobotany, macro-botanical remains, micro-botanical remains. 


\section{Introduction}

Morphometrics is the study of the form, comprising size and shape measurements of objects. Data generated from morphometric analysis can be used for the description and statistical analysis of form variation within and among objects and the study of changes in form (Rohlf and Marcus 1993). Morphometric analysis has become a powerful tool in archaeobotanical research over the last few decades, offering a quantitative alternative and/or extension to conventional archaeobotanical procedures.

Morphometrics can be split into two main approaches. Traditional morphometrics involves the calculation of linear measurements and shape descriptors of objects. These include lengths and widths, as well as size-dependant descriptors such as areas and volumes, and shape measurements such as roundness and aspect ratio. In the 1980's a new approach to morphometric analysis revolutionised the study of form. Known today as geometric modern morphometrics (GMM), this approach uses computer-assisted image analysis and the statistical theory of shape to establish comparisons among different objects by analysing object landmarks along different Cartesian coordinates (for historical reviews see Rohlf and Marcus 1993; Adams et al. 2004; for comparison of methods see Mitteroecker and Gunz 2009, and references therein). With theoretical advances and increased application, GMM has proven especially useful in evolutionary biology studies, including taxonomy and systematics, as well as in anthropological, zoological and botanical research. GMM has also been used in archaeological research. A pioneering application of GMM in archaeology explored the alignment of megalithic standing stones (Kendall and Kendall 1980; Kendall 1984). Since the work of the Kendalls, GMM has been applied in artefact studies, such as lithics and pottery (e.g. Archer and Braun 2010; Thulman 2012; Wilczek et al. 2014), and in zooarchaeological studies such as the taxonomy, domestication and spread of suids (e.g. Cucchi et al. 2009, 2011a; Evin et al. 2013, 2015), dogs (Drake et al. 2015), horses (Seetah et al. 2014), and rodents (Cucchi et al. 2011b, 2014; Valenzuela-Lamas et al. 2011).

Over the last three decades both landmark-based and outline-based GMM, as well as traditional morphometric analysis, have been used in archaeobotanical research. The ability of these morphometric analyses to quantify subtle size and shape differences among plant macro-remains such as seeds and charcoal, as well as micro-remains such as phytoliths, pollen and starch grains, has helped archaeobotanists improve taxonomic resolution, especially when the diagnostic features of taxa overlap. Further, morphometrics has helped researchers better study within-species variations in plant remains, giving them the ability in 
some cases to recognize below-species varieties or landraces, an ability normally beyond the scope of traditional archaeobotanical approaches. Morphometrics has developed independently in the various archaeobotanical disciplines. This is to be expected due to the differences in the kinds of plant remains studied and their taphonomy, as well as the varied range of research questions pursued in the different disciplines.

In this paper we will present an overview of advances in the use of morphometrics in archaeobotanical research for various types of plant remains, its applications in improving taxonomic resolution, and its contributions to addressing major research questions and challenges in archaeobotany. We will also discuss several possible future directions for morphometric analysis being explored by archaeobotanists and propose further perspectives and possible route-ways of development in the conclusions.

\section{An overview of morphometrics in archaeobotany}

\section{Seeds}

The importance of accurate taxonomic identifications has long been recognised in the study of macroscopic archaeobotanical remains (e.g. Goddard and Nesbitt 1997; Jones 1998). Macroscopic identification is normally based on key diagnostic features of remains (most often seeds) which are usually distinctive to the level of genus or species. Although a rapid and efficient method for identification, the recognition of diagnostic features is ill-suited to quantifying variation within a population. Consequently, taxonomic identification by eye has long been aided by morphometric analysis. The size of seeds has, in some cases, been shown to aid the differentiation of taxa, most commonly to distinguish wild progenitors and domesticates of a crop, for example for lentil seeds (van Zeist and Bakker-Heeres 1985). Further, decades of measuring seeds has produced a large body of data that allows changes in crop seed size to be charted during and after domestication (e.g. Willcox 2004; Fuller 2007; Fuller et al. 2017). While these findings are invaluable in understanding the origins of agriculture, the gradual increase in crop seed size in the data indicate, and a lack of a "step change" in size associated with domestication, casts doubt on the appropriateness of size as a means to achieve progenitor-domesticate distinction for individual remains. Shape measurements have also proven to be informative for taxonomic distinction. Shape analysis of seeds has long been based on the ratio of linear measurements. For example, grain breadth:thickness ratios can differentiate some wheat species (Colledge 2001), various lengths of grape pips can differentiate some wild and cultivated forms (Mangafa and Kotsakis 
1996; Fuller 2018) and various shape descriptors (e.g. solidity and elongation) aid the identification of Myosotis seeds (Brinkkemper et al. 2011).

In recent years shape analysis based on GMM has provided the ability to achieve levels of taxonomic accuracy not usually possible based on traditional approaches. In particular, studies of present-day fruit crop remains, traditionally identified only to genus, have shown that both species and variety can be distinguished by GMM analysis, for grapevine pips (Vitis vinifera L.) (Terral et al. 2010; Orrù et al. 2013), date palm seeds (Phoenix dactylifera L.) (Terral et al. 2012), cherry stones (Prunus avium L.) (Burger et al. 2011) and olive stones (Olea europaea L.) (Terral et al. 2004, 2014; Newton et al. 2006). In these cases, outline-based GMM, often with two homologous landmarks for alignment, has been especially effective. These advances in morphometric analysis have had a profound impact on the study of fruit crops, providing the means to chart the use and spread of individual varieties through the archaeological record, opening an entirely new avenue to the study of fruit crops (Terral et al. 2010; Bouby et al. 2013; Pagnoux et al. 2015).

A persistent concern for archaeobotanists in the use of morphometric analysis for studying seed remains is the effects of charring during seed preservation, which alters both seed size and shape. The effects of charring on fruit crop seeds have been extensively studied experimentally (e.g. Bouby et al. 2018; Ucchesu et al. 2016). These studies show that although charring does increase variation in the shape of remains, the predictability of the effect still allows for informative GMM analysis. It has long been established that the charring of starch-rich cereal seeds tends to shorten and broaden the seeds (Wilson 1984; Boardman and Jones 1990; Charles et al. 2015). Comparisons of seeds pre- and post-charring, however, has demonstrated that the effect on shape (rather than size) is modest and consistent for both barley (Ros et al. 2014; Bonhomme et al. 2017) and wheat grains (Bonhomme et al. 2017). Thus, while extreme charring conditions will eventually result in severe distortion (e.g. Braadbaart 2008), if researchers target well-preserved remains for analysis, i.e. those lacking gross charring deformations (Charles et al. 2015), the effects of charring need not prevent informative morphometric analysis. The potential of GMM to contribute to identifications of charred material has already been demonstrated for millets, for which landmarks around the embryo scutellum have been shown to differentiate species normally grouped only at the genera level (García-Granero et al. 2016).

Successes in the GMM study of fruit crop remains and reassuring results from charring experiments, thus, indicate that morphometrics of plant macro-remains has the potential to greatly aid the taxonomic accuracy of identifications (such as for wild seeds or 
crop remains with overlapping diagnostic features) and to provide novel data for as yet understudied aspects of archaeobotanical research, such as the role of landraces in early agriculture (Wallace et al. 2018).

\section{Wood charcoal}

Limitations on taxonomic resolution in anthracology can vary considerably with taxon, in some cases only allowing identification to family, subfamily, or genus level. For some species with great economic importance, these limitations can be extremely important. For example, it is not possible using traditional methods to differentiate anatomically between cultivated and wild species in Olea and Vitis. To solve these taxonomic problems, researchers in recent years have sought to deepen their knowledge of these taxa, beyond anatomy, using different methodologies, including morphometric analyses.

Morphometric studies of woody material have been conducted gradually and increasingly over the last few decades (e.g. Badal-García 1984; Grau-Almero 1984; Vernet et al. 1987; Solari 1988 cited in Durand and Terral 2005). In recent years, morphometrics have been used to identify quantitative differences in the anatomical characteristics of wood and charcoal among wild and cultivated taxa. For example, various statistical procedures have been used to analyze morphometric data such as growth ring width, the number of vessels per group, vessel surface area and vessel density, in the study of wild and domesticated olive and grape taxa (Terral 1996, 1997a and b, 1999, 2000, 2002; Terral and Arnold-Simard 1996; Durand and Terral 2005). Further, we know that environmental conditions can modify the anatomical structure of wood by influencing its growth and development. For example, humidity, drought and pruning can all affect wood density (Schweingruber 2007; Schweingruber et al. 2008; Terral et al. 2009). This suggests that morphometric analysis of any anatomical changes conditioned by the environmental changes that result from the management of crops have the potential to discriminate between wild and cultivated species, and significantly impact future research.

\section{Phytoliths}

Morphometrics has become a valuable tool for identifying or distinguishing between phytoliths produced by closely related species in certain taxa. Morphometric phytolith research was pioneered by Ball and colleagues (Ball and Brotherson 1992; Ball et al. 1993) and Rovner and Russ (1992). As morphometric techniques are becoming more widely used in recent years, the board of the International Phytolith Society (IPS) appointed the International 
Committee for Phytolith Morphometrics (ICPM) to establish methodological standards for the discipline. The current recommendations for a paradigm for its application, criteria for data collection, reporting and publication, key terms and definitions for basic measurements, and software for computer-assisted image analysis can be found in Ball et al. (2016).

Most phytolith morphometric studies are based on measurements of the size and shape of individual or single-celled phytoliths. Pearsall et al. (1995) and Zhao et al. (1998) used morphometric analysis to distinguish between wild and domesticated rice phytoliths. Ball and colleagues $(1996,1999)$ developed morphometric paradigms for discriminating between inflorescence morphotypes produced by several species of wheat and barley (for a review see Ball et al. 2009). Portillo et al. (2006) used those paradigms for differentiating between inflorescence phytoliths from several oat species, while Vrydaghs, et al. (2009) used these for distinguishing the volcaniform morphotypes of bananas. Lu et al. (2009), Zhang et al. (2011, 2018), Kealhofer et al. (2015) and Ge et al. (2018) applied morphometrics for differentiating between millet species, and Out and colleagues $(2014,2016)$ used morphometric methods for differentiating between bilobate phytoliths produced by the leaves of millet crops. The development of such identification methods for leaves and other parts of cereals is expected to facilitate the detection of crop by-products at archaeological contexts and therefore their use as fodder, basketry, thatching, building material, or fuel (Out et al. 2014, Out and Madella 2017).

Morphometric analyses of phytoliths have been applied in investigating early crop processing, storage, and food supply, non-dietary secondary products such as cereal byproducts, livestock dung, and the symbolic value of plants in burial rituals (Berlin et al. 2003; Albert et al. 2008; Portillo et al. 2009, 2010, 2013; Portillo and Albert 2011, 2014a-b; Pető et al. 2013; Out et al. 2016; Wang et al. 2016). As a case-study, integrated biochemical and plant microfossil analyses, including phytolith morphometrics and starch analyses, revealed an advanced beer-brewing technology defined by specialised tools and favourable fermentation conditions around 5,000 years ago, thus predating macro-botanical remains of barley in China by 1,000 years (Wang et al. 2016). In this study phytoliths from barley (Hordeum vulgare) were successfully identified by applying a recently developed method based on the morphometrics of articulated or multi-celled dendritic phytoliths (Ball et al. 2017).

The development of phytolith systematics using morphometrics faces some challenges. For example, the morphometry of articulated phytoliths is still understudied. Moreover, size parameters for phytoliths often appear to have restricted diagnostic strength 
due to variation caused by environmental conditions and the amount of silica accumulation within plant cells. Fortunately, variables of shape appear to be more reliable since they seem to be less influenced by environmental conditions (Ball and Brotherson 1992), but more research needs to be conducted on the effects environmental and taphonomic factors have on phytolith morphometry to confirm this.

\section{Pollen}

Morphometric pollen research was pioneered by Firbas (1937), Rowley (1960), Beug (1961), Andersen and Bertelsen (1972), Andersen (1978), Köhler and Lange (1979) and Dickson (1988). More recently, Tweddle et al. (2005) and Joly et al. (2007) have shown the value of applying multivariate statistical analysis in pollen morphometrics as they studied a large Holocene pollen morphometric dataset obtained from a series of well-dated profiles from England and North-western France respectively.

To date, morphometric analyses have primarily been used in archaeopalynology to distinguish among cereals and wild Poaceae pollen (Leroi-Gourhan 1969; Bottema 1992; Diot 1992; López-Sáez et al. 2003, 2013). These analyses have proven to be of great importance in the study of the origin and diffusion of agriculture at different temporal and spatial scales, as well as in the determination of ecosystem resilience and vulnerability patterns in the face of human impact and climate variability (Gil-Romera et al. 2010; Cruz et al. 2014; Lillios et al. 2016; López-Sáez et al. 2016; Arranz-Otaegui et al. 2017). For example, in the absence of macro-remains, pollen morphometric studies have been used to identify the first evidence of agriculture in Northern and Southern Spain and Portugal between the $6^{\text {th }}$ and the $4^{\text {th }}$ millennia cal. BC (López-Sáez et al. 2005, 2007, 2010, 2011and b; López-Merino et al. 2010; Cortés et al. 2012). However, it is necessary to point out that because preservation issues sometimes prohibit accurate or confident identification of pollen surface patterns (Tweddle et al. 2005) the findings of these studies must be supported by the taphonomic considerations of each sedimentary deposit (López-Sáez et al. 2003, 2006).

Based on morphometric features, researchers have been able to distinguish the monoporate "Cerealia" pollen type produced by cereal species and a limited number of native wild grasses (Beug 2004; Behre 2007), from the pollen of many undomesticated grasses. They have even been able to separate the Cerealia pollen type into different subtypes on the basis of pollen and pore diameter, annulus width and surface structures (Tweddle et al. 2005). For example, in Western Europe, a pollen grain diameter greater than $45 \mu \mathrm{m}$ and an annulus diameter greater than $8 \mu \mathrm{m}$ is typical of cereals (Beug 2004; López-Sáez and López-Merino 
2005). However, in the seaboard and precoastal areas where the indigenous grass species have larger sized pollen grains the morphometric threshold for cereal pollen identification has to be raised to $47 \mu \mathrm{m}$ and $11 \mu \mathrm{m}$ for grain and annulus diameters respectively (Joly et al. 2007).

Morphometric studies have also been used to differentiate between hemp (Cannabis sativa) and hop (Humulus lupulus) pollen (Guerra-Doce and López-Sáez 2006). Cannabis spp. and Humulus spp. have very similar triporate (rarely with 4 or 2 pores) grains. They were initially included in the Humulus lupulus-type by Punt and Malotaux (1984) and in the Cannabis sativa-type by Moore et al. (1991), although currently both are usually referred as Cannabis/Humulus-type in most pollen diagrams (Long et al. 2017). Hemp has been an important economic crop of Eurasia (Long et al. 2017). However, because hemp and hop pollen are so similar, in the absence of seeds (achenes) or fibres, it has been difficult for researchers to confidently infer local hemp cultivation of male plants and/or site retting from simple variations in the values for Cannabis/Humulus-type pollen (Gaillard and Berglund 1988; Edwards and Whittington 1992; Mercuri et al. 2002). Morphometrics have helped solve the problem. Godwin (1967), Whittington and Gordon (1986), Whittington and Edwards (1989), Fleming and Clarke (1998) and Mercuri et al. (2002) were able to use differences in such morphometrics as exine, pore protusion and grain size to differentiate between the two genera.

\section{Starch grains}

Starch grain analyses have produced significant data for understanding the use of plants in the past and the origin of agriculture in different regions of the world (Ugent et al. 1986; Loy et al. 1992; Piperno and Pearsall 1998; Denham et al. 2003; Barton 2005; Fullagar et al. 2006; Dickau et al. 2007; Aceituno and Loaiza 2014). Moreover, in recent decades, analysis of ancient starch has assumed a significant role in bioarchaeological studies (Piperno 2006; Gott et al. 2006; Wilson et al. 2010; Pagan 2015; Torrence 2006a) and in studies of the preservation of these organic residues in different contexts such as stone tools, pottery, soils, and dental calculus (Barton and Matthews 2006; Hardy and Piperno 2008; Hardy et al. 2009). In most archaeological studies of starch, taxonomic identification is made by comparing the gross or general size, shape, and optical attributes of ancient granules with those of reference collections (Torrence 2006b; Ugent 2006), but a limited number have developed automated systems of identification (Torrence et al. 2004; Wilson et al. 2010; Aceituno and López-Sáez 2012; Coster and Field 2015; Arráiz et al. 2016; Mercader et al. 2018). 
Morphometric analysis has helped researchers to quantify the morphologic variability and shape of starch grains. For example, Torrence and colleagues (2004) used multivariate statistical analysis of starch grain surface area measurements, along with qualitative criteria, to discriminate among grains produced by different taxa in Papua New Guinea. Aceituno and López-Sáez (2012), in a case study on modern starch grains of the Iberian Peninsula, were able to distinguish among several species of wheat and barley starch grains, grasses with similar granules by combining a cluster analysis of size measurements. Arráiz et el. (2016) and Mercader et al. (2018) analysed starch grains produced by plants exploited by indigenous communities in Sub-Saharan Africa to evaluate morphometric variations among taxa and the reliability of large datasets; the latter work is the largest reference collection published to date, consisting of 23,100 starch granules from 77 species.

There are yet many avenues in which morphometric analysis of starch grains need to be explored and improved. For example, Coster and Field (2015) have discussed and illustrated the possibility of developing classifier learning algorithms by taking reference measurements (e.g. area, perimeter and position of centre of mass) of starch grains of known plants and then using the algorithms to place measurements of unidentified samples, such as archaeological samples, into known groups or categories. Furthermore, could a GMM type approach that relies on the measurement of a high number of reference points on a set of starch grains provide data to more objectively compare archaeological samples and reference collections? We note that any such measurements could, and should, consider both 2-D and 3-D morphology and orientation as the grain shape changes depending on the plane that is being observed. Perhaps even the simple calculation of the averages, standard deviations and confidence intervals for the average measurements of grains could provide data that would help researchers more reliably compare the values of the archaeological starch grains with those of reference collections. In conclusion, the application of specialised software and statistical analysis aims to improve morphological identification and reduce the degree of subjectivity involved.

\section{Conclusions}

The application of morphometric approaches in archaeobotany has matured over the last few decades. Morphometrics have been shown to improve both the identification and interpretation of a wide range of plant macro and micro-remains. These have particularly contributed to the study of the domestication and spread of many crops around the globe, 
such as cereals and legumes, underground storage organs (USO), and fruit crops, including olives, grapes, dates, and bananas (e.g. Terral et al. 2004, 2010, 2012; Willcox 2004; Fuller 2007, 2017; Ball et al. 2016, and references therein).

Although much has been accomplished, the possibilities for future avenues of morphometric research in archaeobotany remain many and critical. Several specific priority areas for future morphometric research have been identified for individual fields of archaeobotany above, but three general priorities for morphometric archaeobotany are highlighted here. First, a key consideration is that the range of taxa in each respective field of archaeobotany is narrow, and it is critical that taxa important to archaeological research questions are targeted for morphometric research. Second, the availability of published morphometric data and the standardisation of protocols requires attention in many fields, and perhaps here the efforts in the phytolith community can guide or inspire others (Ball et al. 2016). The standardisation of morphometric protocols is especially important as new approaches become more widely available, for example 3-D shape data is becoming easier to acquire and poses challenges that differ from those of handling 2-D data. The potential contribution of developing the powerful visualization tools of GMM to further investigate micro-botanical remains such as phytoliths, pollen and starch grains also needs to be evaluated. Thirdly, a common concern is the need for better understanding of the effects of environmental factors, such as growing conditions, as well as taphonomic aspects, such as charring, on plant remain morphometry. Understanding the role of the many factors that can influence the morphometry of plant remains is critical to reliable and robust application of morphometrics in archaeobotany.

Through further experimentation to validate morphometric approaches and to improve the efficiency of methodologies, archaeobotanical morphometrics can address a broad range of archaeobotanical challenges and major research questions (e.g. Bonhomme et al. 2016). As this research is conducted, we anticipate that over the next few years morphometrics will certainly become an increasingly more common, significant and powerful tool for the archaeobotanists.

\section{Acknowledgements}

MP and TBB are founder members of the International Committee for Phytolith Morphometrics (ICPM), appointed and under the direction of the International Phytolith Society (IPS). 


\section{Disclosure statement}

No potential conflict of interest was reported by the authors.

\section{Funding}

MP work was carried out within the framework of the EU Horizon 2020 MICROARCHEODUNG project. This project has received funding from the European Union's Horizon 2020 research and innovation program under the Marie Sklodowska-Curie grant agreement No H2020-MSCA-IF-2015-702529. MW is funded by an anonymous donation to the University of Sheffield matched by the Alumni Office - DARE. CM research is funded by European Research Council advanced grants (ComPAg no. 323842). SPD and MRA were funded by the "Programa Estatal de Promoción del Talento y su Empleabilidad en I+D+i Juan de la Cierva".

\section{Notes on contributors}

Dr Marta Portillo was a Marie Sklodowska Curie Fellow at the University of Reading. She is an environmental archaeologist specialised in phytoliths in integration with geoarchaeological methods, as well as with experimental and ethnoarchaeological approaches. Her field of expertise investigates human-environment interactions and the developments of cultural, economic and technological behaviours in the Western Mediterranean and the Near East. She currently serves at the board of the International Phytolith Society (IPS).

Dr Terry Ball is a Professor of Ancient Scripture at Brigham Young University. PhD in Archaeobotany specialised in phytolith systematics, morphometrics, and Old World cereals. Recent publications include co-authoring Phytoliths as a tool for investigations of agricultural origins and dispersals around the world, Morphometric Analysis of phytoliths: recommendations towards standardization from the International Committee for Phytolith Morphometrics, and A morphometric study of variance in articulated dendritic phytolith wave lobes within selected species of Triticeae and Aveneae.

Dr Michael Wallace is a prehistorian and archaeobotanist whose research focuses on the emergence, spread and development of the agricultural way of life. Michael utilises a diverse set of innovative analytical approaches including stable isotopes, morphometrics and 'big data' statistics.

Dr Charlene Murphy is an archaeobotanist primarily working in South Asia. Her recent publications include work on South Asian pulses Cajanus cajanus (pigeon pea) and Macrotyloma uniflorium (horse gram) as well as aspects of indigenous agricultural domestication in South Asia.

Dr Sebastián Pérez-Díaz is an environmental archaeologist currently at the CNRS UMR 5600 (University of Lyon). His main research is focused on the interactions between humans and the ecosystem along the Western Mediterranean, from the analysis of vegetal 
microremains (pollens, spores and non-pollen palynomorphs) and other palaeoenvironmental tools (magnetic susceptibility, loss-on-ignition, microcharcoals). He has published recent articles in journals such as Vegetation History and Archaeobotany, Journal of Archaeological Science: Reports, The Holocene, and Quaternary International.

Dr Mónica Ruiz Alonso is an archaeobotanist specialised in wood charcoal and her research focuses on the management of plant resources both in the Pleistocene and Holocene of southwest Europe. She works in different archaeological sites in Spain, Portugal, Italy and Morocco, among others.

Dr Francisco Javier Aceituno is a Professor in Archaeology at the University of Antioquia, expert in neotropical archaeology, early peopling of South America and origins of agriculture in the Americas. He has recently published, among other journals, in Quaternary Science Reviews, Quaternary International, Journal of Anthropological Archaeology, Journal of Archaeological Science, and Latin American Antiquity.

Dr José Antonio López-Sáez, a Tenured Scientist at the Institute of History (Spanish National Research Council), writes on aspects related to prehistoric plant use, anthropisation dynamics and the origin of agriculture. He has also carried out various palaeoecological projects focusing on climatic change and cultural response. Among his most recent articles are those published in SCI journals such as Quaternary Science Reviews, Review of Palaeobotany and Palynology, Quaternary International, Journal of Archaeological Science: Reports, The Holocene, Quaternary Research, and Vegetation History and Archaeobotany.

\section{ORCID}

Marta Portillo ID http://orcid.org/0000-0002-2703-031X

Michael Wallace ID https://orcid.org/0000-0002-2355-5565

Charlene Murphy ID https://orcid.org/0000-0003-1486-9439

Sebastián Pérez-Díaz ID http://orcid.org/0000-0002-2702-0058

Mónica Ruiz Alonso ID http://orcid.org/0000-0002-7794-4451

Francisco Javier Aceituno ID http://orcid.org/0000-0002-5727-8826

José Antonio López-Sáez ID http://orcid.org/0000-0002-3122-2744

\section{References}

Aceituno, F.J., and N. Loaiza. 2014. "Early and Middle Holocene evidence for use of plants and cultivation in the Middle Cauca River Basin, Cordillera Central (Colombia)". Quaternary Science Reviews 86: 49-62.

Aceituno, F.J. and J. A. López-Sáez. 2012. "Caracterización morfológica de almidones de los géneros Triticum y Hordeum en la Península Ibérica”. Trabajos de Prehistoria 69 (2): 332348.

Adams, D. C., F.J. Rohlf, and D.E. Slice. 2004. "Geometric morphometrics: Ten years of progress following the "revolution". Italian Journal of Zoology 71 (9): 5-16.

Albert, R.M., R. Shahack-Gross, D. Cabanes, A. Gilboa, S. Lev-Yadun, M. Portillo, I. Sharon, E.Boaretto, and S. Weiner. 2008. "Phytolith-rich layers from the Late Bronze and 
Iron Ages at Tel Dor (Israel): mode of formation and archaeological significance." Journal of Archaeological Science 35 (1):57-75.

Andersen, S.T. 1978. "Identification of wild grass and cereal pollen". Danmarks Geologiske Undersøgelse Arbog 1978: 69-92.

Andersen, S.T., and F. Bertelsen. 1972. "Scanning electron microscope studies of pollen of cereals and other grasses". Grana 12: 79-86.

Archer, W., and D.R. Braun. 2010. "Variability in bifacial technology at Elandsfontein, Western cape, South Africa: a geometric morphometric approach". Journal of Archaeological Science 37: 201-209.

Arráiz, H,N. Barbarin, M. Pasturel, L. Beaufort, M. Domínguez-Rodrigo and D. Barboni, 2016. "Starch granules identification and automatic classification based on and extended set of morphometric and optical measurements". Journal of Archaeological Science: Reports 7: 169-179.

Arranz-Otaegui, A., J.A. López-Sáez, J.L. Araus, M. Portillo, A. Balbo, E. Iriarte, L. Gourichon, F. Braemer, L. Zapata, and J.J. Ibáñez. 2017. "Landscape transformations at the dawn of agriculture in southern Syria (10.7-9.9 ka cal. BP): Plant-specific responses to the impact of human activities and climate change". Quaternary Science Reviews 158: 145-163.

Badal-García, E. 1984. "Contribución al estudio de la vegetación prehistórica del sur de Valencia y norte de Alicante a través del análisis antracológicos”. Degree Thesis, University of Valencia.

Ball, T.B., and J.D. Brotherson. 1992. "The effect of varying environmental conditions on phytolith morphology in two species of grass (Bouteloua curtipendula and Panicum virgatum)". Scanning Microscopy 6: 1163-1182.

Ball, T.B., J.D. Brotherson, and J.S. Gardner. 1993. "A typologic and morphometric study of variation in phytoliths from einkorn wheat (Triticum monococcum)". Canadian Journal of Botany 71: 1182-1192.

Ball, T.B., J.D. Brotherson, and J.S. Gardner. 1996. "Identifying phytoliths produced by the inflorescence bracts of three species of wheat (Triticum monoccocum L., $T$. dicoccon Schrank, and T. aestivum L.) using computer-assisted image and statistical analyses". Journal of Archaeological Science 23: 619-632.

Ball, T.B., J.S. Gardner, and N. Anderson. 1999. "Identifying inflorescence phytoliths from selected species of wheat (Triticum monoccum, T. dicoccon, T. dicoccoides, and T. aestivum) and barley (Hordeum vulgare and H. spontaneum)". American Journal of Botany 86 (11): $1615-1623$.

Ball, T.B., R. Ehlers, and M.D. Standing. 2009. "Review of typologic and morphometric analysis of phytoliths produced by wheat and barley". Breeding Science 59: 505-512.

Ball, T.B., A. Davis, R.R. Evett, J.L. Ladwig, M. Tromp, W.A. Out, and M. Portillo. 2016. "Morphometric analysis of phytoliths: recommendations towards standardization from the 
International Committee for Phytolith Morphometrics". Journal of Archaeological Science 68: $106-111$.

Ball, T.B., Vrydaghs, L., Mercer, T., Pearce, M., Snyder, S., Lisztes-Szabó, Z., and A. Pető 2017. "A morphometric study of variance in articulated dendritic phytolith wave lobes within selected species of Triticeae and Aveneae". Vegetation History and Archaeobotany 26: 8597.

Barton, H. 2005. "The case for rainforest foragers: the starch record at Niah Cave, Sarawak". Asian Perspectives 44 (1): 56-72.

Barton, H., and P. J. Matthews. 2006. "Taphonomy". In Ancient Starch Research, edited by R. Torrence and H. Barton 75-94. Walnut Creek, California: Left Coast Press.

Behre, K.E. 2007. "Evidence for Mesolithic agriculture in and around central Europe?" Vegetation History and Archaeobotany 16: 203-219.

Berlin, A.M., T.B. Ball, R. Thompson, D. Kittleson, and S.C. Herbert. 2003. "Ptolemaic agriculture, "Syrian wheat", and Triticum aestivum". Journal of Archaeological Science 30: $115-121$.

Beug, H.J. 1961. Leitfaden der Pollenbestimmung für Mitteleuropa und angrenzende Gebiete. Stuttgart: Gustav Fischer Verlag.

Beug, H.J. 2004. Leitfaden der Pollenbestimmung für Mitteleuropa und angrenzende Gebiete. München: Verlag Dr. Friedrich Pfeil.

Boardman, S., and G. Jones. 1990. "Experiments on the Effects of Charring on Cereal Plant Components". Journal of Archaeological Science 17: 1-11.

Bonhomme, V., Forster, E., Wallace, M., Stillman, E., Charles, M., and G. Jones. 2016. "The first shoots of a modern morphometrics approach to the origins of agriculture" Web Ecology 16: $1-2$.

Bonhomme, V., Forster, E., Wallace, M., Stillman, E., Charles, M., and G. Jones. 2017. "Identification of inter- and intra-species variation in cereal grains through geometric morphometric analysis, and its resilience under experimental charring". Journal of Archaeological Science 86: 60-67.

Bottema, S. 1992. "Cereal-type pollen in the Near East as indicators of wild or domestic crops". In Préhistoire de l'agriculture: nouvelles approches expérimentales et ethnographiques, edited by P.C. Anderson, 95-106. Sophia-Antipolis: Éditions du CNRS.

Bouby, L., Figueiral, I., Bouchette, A., Rovira, N., Ivorra, S., Lacombe, T., Pastor, T., Picq, S., Marinval, P., and J.-F. Terral. 2013. "Bioarchaeological Insights into the Process of Domestication of Grapevine (Vitis vinifera L.) during Roman Times in Southern France". PLOS ONE 8 (5): e63195.

Bouby, L., Bonhomme, V., Ivorra, S., Pastor, T., Rovira, N., Tillier, M., Pagnoux, C., and J.F. Terral, 2018. "Back from burn out: are experimentally charred grapevine pips too 
distorted to be characterized using morphometrics?" Archaeological and Anthropological Sciences, 10(4): 943-954.

Braadbaart, F. 2008. "Carbonisation and morphological changes in modern dehusked and husked Triticum dicoccum and Triticum aestivum grains". Vegetation History and Archaeobotany 17(1): 155-166.

Brinkkemper, O., van der Maaten, L., and P. Boon, 2011. "Identification of Myosotis seeds by means of digital image analysis". Vegetation History and Archaeobotany 20(5): 435-445.

Burger, P., Terral, J.-F., Ruas, M.-P., Ivorra, S., and S. Picq. 2011. "Assessing past agrobiodiversity of Prunus avium L. (Rosaceae): a morphometric approach focused on the stones from the archaeological site Hôtel-Dieu (16th century, Tours, France)". Vegetation History and Archaeobotany 20: 447-458.

Charles, M., Forster, E., Wallace, M., and G. Jones. 2015. "Nor ever lightning char thy grain"1: establishing archaeologically relevant charring conditions and their effect on glume wheat grain morphology. STAR: Science \& Technology of Archaeological Research 1: 1-6.

Colledge, S. 2001. "Plant exploitation on epipalaeolithic and early neolithic sites in the Levant”. British Archaeological Reports International Series 986: 1-256.

Cortés, M., F. Jiménez, M.D. Simón, J.F. Gibaja, A. Faustino, F. Martínez, M. Rodrigo, J.A. Flores, A. Paytan, J.A. López-Sáez, L. Peña, J.S. Carrión, A. Morales, E. Roselló, J.A. Riquelme, R.M. Dean, E. Salgueiro, R.M. Martínez, J.J. De la Rubia, M.C. Lozano, J.L. Vera, L. Llorente, and N.F. Bicho. 2012. "The Mesolithic-Neolithic transition in southern Iberia". Quaternary Research 77: 221-234.

Coster, A. and J.H.Field. 2015. "What starch grain is that? e A geometric morphometric approach to determining plant species origin". Journal of Archaoelogical Science 58: 9-25.

Cruz, M., M. Sebastián, A. Uriarte, and J.A. López-Sáez. 2014. "Landscape construction and long-term economic practices: an example from the Spanish Mediterranean uplands through Rock Art archaeology". Journal of Archaeological Method and Theory 21: 589-615.

Cucchi, T., M. Fujita, and K. Dobney. 2009. "New insights into pig taxonomy, domestication and human dispersal in Island South East Asia: molar shape analysis of Sus remains from Niah Caves, Sarawak”. International Journal of Osteoarchaeology 19: 508-530.

Cucchi, T., A. Hulme-Beaman, J. Yuan, and K. Dobney. 2011a. "Early Neolithic pig domestication at Jiahu, Henan Province, China: clues from molar shape analyses using geometric morphometric approaches". Journal of Archaeological Science 38: 11-22.

Cucchi, T., A. Bălăşescu, C. Bem, V. Radu, J.D. Vigne, and A. Tresset. 2011b. "New insights into the invasive process of the eastern house mouse (Mus musculus musculus): evidence from the burnt houses of Chalcolithic Romania". The Holocene 21: 1195-1202.

Cucchi, T., R. Barnett, N. Martínková, S. Renaud, E. Renvoisé, A. Evin, A. Sheridan, I. Mainland, C. Wickham-Jones, C. Tougard, J.P. Quéré, M. Pascal, G. Heckel, P. O'Higgins, J.B. Searle, and K.M. Dobney. 2014. "The changing pace of insular life: 5000 years of 
microevolution in the Orkney vole (Microtus arvalis orcadensis)". Evolution 68 (10): 28042820.

Denham, T. P., S. G. Haberle, C. Lentfer, R. Fullagar, J. Field, M. Therin, N. Porch, and B. Winsborough. 2003. "Origins of agriculture at Kuk Swamp, in the Highlands of New Guinea". Science 301: 189-93.

Dickau, R., A.J Ranere, and R. Cooke. 2007. "Starch grain evidence for the preceramic dispersals of maize and root crops into tropical dry and humid forest of Panama". Proceedings of the National Academy of Sciences of the United States of America 14: 36513656.

Dickson, C. 1988. "Distinguishing cereal from wild grass pollen: some limitations". Circaea 5: $67-71$.

Diot, M.F. 1992. "Études palynologiques des blés sauvages et domestiques issus de cultures expérimentales". In Préhistoire de l'agriculture: nouvelles approches expérimentales et ethnographiques, edited by P.C. Anderson, 107-111. Sophia-Antipolis: Éditions du CNRS.

Drake A.C., Coquerelle M., and G. Colombeau. 2015. "3D morphometric analysis of fossil canid skulls contradicts the suggested domestication of dogs during the late Paleolithic". Scientific Reports 5: 8299.

Durand, A., and J.F. Terral. 2005. "Regarder autrement le charbon de bois archéologique: l'exemple de l'irrigation des plantations d'oliviers en France méridionale et en Catalogne (IXe-XVe siècle). Archéologie du Midi Médiéval". Association Centre d'Archéologie Médiévale du Languedoc (C.A.M.L.) 23-24: 75-92.

Edwards, K.J., and G. Whittington. 1992. "Male and female plant selection in the cultivation of hemp, and variations in fossil Cannabis pollen representation". The Holocene 2 (1): 85-87.

Evin, A., T. Cucchi, A. Cardini, U.S. Vidarsdottir, G. Larson, and K. Dobney. 2013. "The long and winding road: identifying pig domestication through molar size and shape". Journal of Archaeological Science 40: 735-743.

Evin, A., L.G. Flink, A. Bălăşescu, D. Popovici, R. Andreescu, D. Bailey, P. Mirea, C. Lazăr, A. Boroneanţ, C. Bonsall, U.S. Vidarsdottir, S. Brehard, A. Tresset, T. Cucchi, G. Larson, and K. Dobney. 2015. "Unravelling the complexity of domestication: a case study using morphometrics and ancient DNA analyses of archaeological pigs from Romania". Philosophical Transactions of the Royal Society Biological Science 370: 20130616.

Firbas, F. 1937. "Der Pollenanalytysche Nachweiss des Getreidenbaus". Zeitschrift für Botanik 31: 447-478.

Fleming M.P., and R.C. Clarke. 1998. "Physical evidence for the antiquity of Cannabis sativa L.". Journal of the International Hemp Association 5: 80-92.

Fullagar, R., J. Field, T. Denham, and C. Lentfer. 2006. "Early and Mid-Holocene tool-use and processing of taro (Colocasia esculenta), yam (Dioscorea sp.) and other plants at Kuk 
Swamp in the highlands of Papua New Guinea". Journal of Archaeological Science 33: 595614.

Fuller, D.Q. 2007. "Contrasting patterns in crop domestication and domestication rates: recent archaeobotanical insights from the Old World". Annals of Botany 100 (5): 903-924.

Fuller, D.Q. 2018. "Long and attenuated: comparative trends in the domestication of tree fruits”. Vegetation History and Archaeobotany 27 (1): 165-176.

Fuller, D.Q., Colledge, S., Murphy, C., and C. Stevens. 2017. "Sizing up cereal variation: patterns in grain evolution revealed in chronological and geographical comparisons". In Miscelánea en homenaje a Lydia Zapata Peña (1965-2015), edited by J. Fernández Eraso, J.A. Mujika Alustiza, A. Arrizabalaga Valbuena, and M. García Díez, 131-149. Bilbao: Universidad del País Vasco.

Gaillard, M.J., and B.E. Berglund. 1988. "Land-use history during the last 2700 years in the area of Bjaresjö, southern Sweden”. In The cultural landscape - past, present and future, edited by H.H. Birks, H.J.B. Birks, P.E. Kaland and D. Moe, 409-428. Cambridge: Cambridge University Press.

García-Granero, J.J., Arias-Martorell, J., Madella, M., and C. Lancelotti. 2016. "Geometric morphometric analysis of Setaria italica (L.) P. Beauv. (foxtail millet) and Brachiaria ramosa (L.) Stapf. (browntop millet) and its implications for understanding the biogeography of small millets". Vegetation History and Archaeobotany 25: 303-310.

Ge, Y., H. Lu, J., Zhang, C., Wang, K., He, and X. Huan, 2018. "Phytolith analysis for the identification of barnyard millet (Echinochloa sp.) and its implications". Archaeological and Anthropological Sciences, 10 (1): 61-73.

Gil-Romera, G., L. López, J.S. Carrión, P. González, C. Martín, J.A. López-Sáez, S. Fernández, M. García, and V. Stefanova. 2010. "Interpreting resilience through long-term ecology: potential insights in Western Mediterranean landscapes". The Open Ecology Journal 3: $43-53$

Goddard J., and M. Nesbitt. 1997. "Why draw seeds? Illustrating archaeobotany". Graphic Archaeology 4: 13-21.

Godwin, H. 1967. "Pollen-analytic evidence for the cultivation of Cannabis in England". Review of Palaeobotany and Palynology 4: 71-80.

Gott, B., H. Barton, D. Samuel, and R. Torrence. 2006. "Biology of starch". In Ancient Starch Research, edited by R. Torrence and H. Barton, 35-45. Walnut Creek, California: Left Coast Press.

Grau-Almero, E. 1984. "El hombre et la vegetación del Neolítico a la Edad del Bronce Valenciano en la Safor (Provincia de Valencia) según la análisis antracológico de la Cova de la Recambra". Degree Thesis, University of Valencia.

Guerra-Doce E. and J.A. López-Sáez. 2006. "El registro arqueobotánico de plantas psicoactivas en la prehistoria de la Península Ibérica”. Complutum 17: 7-24. 
Hardy, A.G., and D. Piperno. 2008. "Using plant microfossils from dental calculus to recover human diet: a case study from Tell al-Raqa'I, Syria". Journal of Archaeological Science 35: 1943-1950.

Hardy, K., Blakney, T., Copeland. L., Kirkham. J., Wrangham, R., and M. Collins. 2009. "Starch granules, dental calculus and new perspectives on ancient diet". Journal of Archaeological Science 36: 248-255.

Joly, C., L. Barillé, M. Barreau, A. Mancheron, and L. Visset. 2007. "Grain and annulus diameter as criteria for distinguishing pollen grains of cereals from wild grasses". Review of Palaeobotany and Palynology 146: 221-233.

Jones, G. 1998. "Wheat grain identification - why bother?" Environmental Archaeology 2: $29-34$.

Kealhofer, L., F. Huang, M., DeVincenzi, and M.M. Kim 2015. "Phytoliths in Chinese foxtail millet (Setaria italica)". Review of Palaeobotany and Palynology, 223: 116-127.

Kendall, D.G. 1984. "Shape manifolds, Procrustean metrics and complex projective spaces". Bulletin of the London Mathematical Society 16 (2): 81-121.

Kendall, D.G. and W.S. Kendall. 1980 "Alignments in two-dimensional random sets of points". Advances in Applied Probability 12: 380-424.

Köhler, E., and E. Lange. 1979. "A contribution to distinguishing cereal from wild grass pollen grains by LM and SEM”. Grana 18: 133-140.

Leroi-Gourhan, A. 1969. "Pollen grains of Gramineae and Cerealia from Shanidar and Zawi Chemi". In The domestication and exploitation of plants and animals, edited by P.J. Ucko and G.W. Dimbleby, 143-148. London: Gerald Duckworth \& Co Ltd.

Lillios, K.T., A. Blanco, B. Lee, and J.A. López-Sáez. 2016. "Mid-Late Holocene climate, demography, and cultural dynamics in Iberia: a multi-proxy approach". Quaternary Science Reviews 135: 138-153.

Long, T., M. Wagner, D. Demske, C. Leipe, and P.E. Tarasov. 2017. "Cannabis in Eurasia: origin and human use and Bronze Age trans-continental connections". Vegetation History and Archaeobotany 26: 245-258.

López-Merino, L., A. Martínez, and J.A. López-Sáez. 2010. "Early agriculture and palaeoenvironmental history in the North of the Iberian Peninsula: a multi-proxy analysis of the Monte Areo mire (Asturias, Spain)". Journal of Archaeological Science 37: 1978-1988.

López-Sáez, J.A., and L. López-Merino. 2005. "Precisiones metodológicas acerca de los indicios paleopalinológicos de agricultura en la Prehistoria de la Península Ibérica". Portugalia 26: 53-64.

López-Sáez, J.A., P. López, and F. Burjachs. 2003. "Arqueopalinología: Síntesis Crítica”. Polen 12: 5-35. 
López-Sáez, J.A., P. López, L. López, E. Cerrillo, A. González, and A. Prada. 2005. "Prehistoric landscapes in North Extremadura between the $\mathrm{VI}^{\text {th }}$ and the $\mathrm{IV}^{\text {th }}$ millenia cal. BC". Journal of Iberian Archaeology 7: 23-35.

López-Sáez, J.A., F. Burjachs, P. López-García, and L. López-Merino. 2006. “Algunas precisiones sobre el muestreo e interpretación de los datos en Arqueopalinología". Polen 15: $17-29$.

López-Sáez, J.A., S. Monteiro, and L. López. 2007. "La transición Mesolítico-Neolítico desde una perspectiva paleoambiental: análisis palinológico del sitio arqueológico de Prazo (Freixo de Numão, Portugal)". Portugalia, 27-28: 19-34.

López-Sáez, J.A., L. López, and S. Pérez Díaz, S. 2010. "Neolitización, megalitismo y antropización del paisaje en Galicia entre el VII y el IV milenio cal. BC". Munibe (Antropologia-Arkeologia) Supl. 32: 488-496.

López-Sáez, J.A., L. López, S. Pérez-Díaz, and F. Alba. 2011a. "Paleopaisajes de Andalucía Oriental durante la transición Mesolítico-Neolítico antiguo". In Os últimos caçadoresrecolectores e as primeiras comunidades produtoras do sul da Península Ibérica e do norte de Marrocos, edited by J.F. Gibaja and A.F. Carvalho, 213-220. Faro: Universidade do Algarve.

López-Sáez, J.A., S. Pérez-Díaz, and F. Alba. 2011b. "Antropización y agricultura en el Neolítico de Andalucía Occidental a partir de la Palinología”. Menga. Revista de Prehistoria de Andalucía 2: 72-85.

López-Sáez, J.A., M.J. Iriarte, and F. Burjachs. 2013. "Arqueopalinología”. In Métodos y técnicas de análisis y estudio en Arqueología Prehistórica. De lo técnico a la reconstrucción de los grupos humanos, edited by M. García and L. Zapata, 273-290. Vitoria: Universidad del País Vasco.

López-Sáez, J.A., D. Abel, S. Robles, S. Pérez-Díaz, F. Alba, and D. Nieto. 2016. "Landscape dynamics and human impact on high-mountain woodlands in the western Spanish Central System during the last three millennia". Journal of Archaeological Science: Reports 9: 203-218.

Loy, T. H., M. Spriggs, and S. Wickler. 1992. "Direct evidence for human use of plants 28,000 years ago: starch residues on stone artifacts from the northern Salomon Islands". Antiquity 66: 898-912.

Lu, H., J. Zhang, N. Wu, K.B. Liu, D. Xu, and Q. Li. 2009. "Phytoliths Analysis for the Discrimination of Foxtail Millet (Setaria italica) and Common Millet (Panicum miliaceum)". PLOS ONE 4 (2): e4448.

Mangafa, M., and K. Kotsakis 1996. "A New Method for the Identification of Wild and Cultivated Charred Grape Seeds". Journal of Archaeological Science 23 (3): 409-418.

Mercader, J, M. Abtosway, R. Bird, M. Bundala, S. Clarke, J. Favreau, J.L. Inwood, M. Itambu, F. Larter, P. Lee, R. Patalano, M. Soto, L. Tucker and D. Walde. 2018. 
"Morphometrics of starch granules from sub-Saharan plants and the taxonomic identification of ancient starch". Frontiers in Earth Science 6: 146.

Mercuri, A.M., C.A. Accorsi, and M. Bandini. 2002. "The long history of Cannabis and its cultivation by the Romans in central Italy, shown by pollen records from Lago Albano and Lago di Nemi". Vegetation History and Archaeobotany 11: 263-276.

Mitteroecker, P., and Ph. Gunz. 2009. "Advances in Geometric Morphometrics". Evolutionary Biology 36 (2): 235-247.

Moore, P.D., J.A. Webb, and M.E. Collison. 1991. Pollen Analysis. $2^{\text {nd }}$ Edition. Oxford: Blackwell.

Newton, C., Terral, J.-F., and S. Ivorra. 2006. "The Egyptian olive (Olea europaea subsp. europaea) in the later first millennium BC: origins and history using the morphometric analysis of olive stones". Antiquity 80: 405-414.

Newton, C., C. Lorre, C. Sauvage, S. Ivorra, and J.F. Terral. 2014. "On the origins and spread of Olea europaea L. (olive) domestication: evidence for shape variation of olive stones at Ugarit, Late Bronze Age, Syria - a window on the Mediterranean Basin and on the westward diffusion of olive varieties". Vegetation History and Archaeobotany 23: 567-575.

Orrù, M., Grillo, O., Lovicu, G., Venora, G., and G. Bacchetta. 2013. "Morphological characterisation of Vitis vinifera L. seeds by image analysis and comparison with archaeological remains". Vegetation History and Archaeobotany 22: 231-242.

Out, W.A., and M. Madella. 2017. "Towards improved detection and identification of crop by-products: Morphometric analysis of bilobate leaf phytoliths of Pennisetum glaucum and Sorghum bicolor". Quaternary International 434: 505-521.

Out, W.A., J.F. Pertusa Grau, and M. Madella. 2014. "A new method for morphometric analysis of opal phytoliths from plants". Microscopy and Microanalysis 20 (6): 1876-1887.

Out, W.A., Ryan, P., García-Granero J.J., Barastegui, J., Maritan, L., Madella, M., and D. Usai. 2016. "Plant exploitation in Neolithic Sudan: A review in the light of new data from the cemeteries R12 and Ghaba". Quaternary International 412: 36-53.

Pagan, J.R. 2015. Almidones: guía de material comparativo moderno del Ecuador para los estudios paleobotánicos en el neotrópico. Aspha, Buenos Aires.

Pagnoux, C., Bouby, L., Ivorra, S., Petit, C., Valamoti, S.-M., Pastor, T., Picq, S., and J.-F. Terral. 2015. "Inferring the agrobiodiversity of Vitis vinifera L. (grapevine) in ancient Greece by comparative shape analysis of archaeological and modern seeds". Vegetation History and Archaeobotany 24: 75-84.

Pearsall, D.M., D.R. Piperno, E.H. Dinan, M. Umlauf, Z. Zhao, and J.R.A. Benefer. 1995. "Distinguishing rice (Oryza sativa Poaceae) from wild Oryza species through phytolith analysis: results of preliminary research". Economic Botany 49: 183-196. 
Petö, A., F. Gyulai, D. Popity, and A. Kenez. 2013. "Macro- and micro-archaeobotanical study of a vessel content from a Late Neolithic structured deposition from southeastern Hungary”. Journal of Archaeological Science 40 (1): 58-71.

Piperno, D. 2006. Phytoliths: a comprehensive guide for archaeologists and paleoecologists. Lanham: AltaMira Press.

Piperno, D., and D. Pearsall. 1998. The origins of agriculture in the lowland Neotropics. San Diego: Academic Press.

Portillo, M., and R.M. Albert. 2011. "Husbandry practices and livestock dung at the Numidian site of Althiburos (el Médéina, Kef Governorate, northern Tunisia): the phytolith and spherulite evidence". Journal of Archaeological Science 38: 3224-3233.

Portillo, M., and R.M. Albert. 2014a. "Early crop cultivation and caprine herding: The evidence from phytolith and fecal spherulite studies". In The Sands of Time: The Desert Neolithic Settlement of Ayn Abü Nukhayla, edited by D.O. Henry and J.E. Beaver, 121-137. Berlin: ex oriente.

Portillo, M., and R.M. Albert. 2014b. "Microfossil evidence for grinding activities". Revista d'Arqueologia de Ponent 24: 103-112.

Portillo, M., T.B. Ball, and J. Manwaring. 2006. "Morphometric analysis of inflorescence phytoliths produced by Avena sativa L. and Avena strigosa Schreb". Economic Botany 60: $121-129$.

Portillo, M., R.M. Albert, and D.O. Henry. 2009. "Domestic activities and spatial distribution in Ain Abū Nukhayla (Wadi Rum, Southern Jordan): The use of phytoliths and spherulites studies". Quaternary International 193: 174-183.

Portillo, M., A.M. Rosen, and M. Weinstein-Evron. 2010. "Plant uses at el-Wad Terrace (Mount Carmel, Israel): The phytolith evidence". Eurasian Prehistory 7: 99-112.

Portillo, M., M. Bofill, M. Molist, and R.M. Albert. 2013. "Phytolith and use-wear functional evidence for grinding stones from the Near East”. In Regards croisés sur les outils liés au travail des végétaux. An interdisciplinary focus on plant working tools, edited by P.C. Anderson, C. Cheval and A. Durand, 161-174. Antibes: Éditions APDCA.

Punt, W., and M. Malotaux. 1984. "Cannabaceae, Moraceae and Urticaceae". In The Northwest European Pollen Flora IV, edited by W. Punt and G.C.S. Clarke, 23-44. Amsterdam: Elsevier.

Rohlf, F.J., and L.F. Marcus. 1993. "A revolution in morphometrics". Trends in Ecology and Evolution 8 (4): 129-132.

Ros, J., A. Evin, L. Bouby, and M.P. Ruas. 2014. "Geometric morphometric analysis of grain shape and the identification of two-rowed barley (Hordeum vulgare subsp. distichum L.) in southern France". Journal of Archaeological Science 41: 568-575. 
Rovner, I., and J.C. Russ. 1992. "Darwin and design in phytolith systematics: Morphometric methods for mitigating redundancy". In Phytolith Systematics: Emerging Issues, edited by G.R. Rapp and S.C. Mullholland, 253-276. New York: Plenum Press.

Rowley, J.R. 1960. "The exine structure of cereal and wild type grass pollen". Grana Palynologica 2: 9-15.

Schweingruber, F.H. 2007. Wood Structure and Environment. Verlag Berlin HeidelbergSpringer

Schweingruber, F.H., A. Börner and E.-D. Schulze. 2008. Atlas of Woody Plant Stems. Evolution, Structure, and Environmental Modifications. Verlag Berlin Heidelberg: Springer.

Seetah K., Cucchi T., Dobney K., and G. Barker. 2014. "A geometric morphometric reevaluation of the use of dental form to explore differences in horse (Equus caballus) populations and its potential zooarchaeological application". Journal of Archaeological Science 41: 904-910.

Solari, M.E. 1988. "Etude anthracologique des niveaux paléolithique supérieur à l'âge du Bronze de la Cova de l'Espérit (Salses, Pyrénées-Orientales)". D.E.A., University of Montpellier II (Sciences et Techniques du Languedoc).

Terral, J.F. 1996. "Wild and cultivated olive (Olea europea L.): a new approach to an old problem using inorganic analyses of modern wood and archaeological charcoal". Review of Palaeobotany and Palynology 91: 383-397.

Terral, J.F. 1997a. "Les débuts de la domestication de l'olivier (Olea europaea L.) en Méditerranée nord-occidentale. Analyse comparative morphométrique appliquée sur matériel anthracologique". Comptes Rendus de l'Academic des Sciences de Paris 324: 417-425.

Terral, J.F. 1997b. "Domestication de l'olivier (Olea europaea L.) en Méditerranée nordoccidentale: approche morphométrique et implications paléoclimatiques". $\mathrm{PhD}$ diss. University of Montpellier II.

Terral, J.F. 1999. "La morphométrie à la recherche des origines de la culture et de la domestication des arbres fruitiers : le modèle de l'olivier en méditerranée nord-occidentale". Revue d'Archéométrie 23: 101-126

Terral, J.F. 2000. "Exploitation and Management of the Olive Tree during Prehistoric Times in Mediterranean France and Spain”. Journal of Archeological Science 27: 127-133.

Terral J.F. 2002. "Quantitative anatomical criteria for discriminating wild grapevine (Vitis vinifera ssp. sylvestris) from cultivated vines (Vitis vinifera ssp. vinifera). British Archaeological Reports International Series 1063: 59-64.

Terral, J.F., and G.Arnold-Simard. 1996. "Beginnings of olive cultivation in relation to Holocene bioclimatic changes". Quaternary Research 46: 176-185.

Terral J.F, N. Alonso, R. Buxó i Capdevila, N. Chatti, L. Fabre, G. Fiorentino, Ph. Marinval, G. Pérez Jordá, B. Pradat, N. Rovira, and P. Alibert. 2004. "Historical biogeography of olive 
domestication (Olea europaea L.) as revealed by geometrical morphometry applied to biological and archaeological material". Journal of Biogeography 31: 63-77.

Terral J.F., A. Durand, C. Newton, and S. Ivorra. 2009. "Archéo-biologie de la domestication de l'olivier en Méditerranée occidentale: de la remise en cause d'une histoire dogmatique à la révélation de son irrigation médiévale". Études héraultaises, Montpellier: Association Etudes sur l'Hérault 233: 13-25.

Terral, J.F., E. Tabard, L. Bouby, S. Ivorra, T. Pastor, I. Figueiral, S. Picq, J.B. Chevance, C. Jung, L. Fabre, C. Tardy, M. Compan, R. Bacilieri, T. Lacombe, and P. This. 2010. Evolution and history of grapevine (Vitis vinifera) under domestication: new morphometric perspectives to understand seed domestication syndrome and reveal origins of ancient European cultivars". Annals of Botany 105 (3): 443-455

Terral, J.F., C. Newton, S. Ivorra, M. Gros-Balthazard, C. Tito de Morais, S. Picq, M. Tengberg, and J.Ch. Pintaud. 2012. "Insights into the historical biogeography of the date palm (Phoenix dactylifera L.) using geometric morphometry of modern and ancient seeds". Journal of Biogeography 39: 929-941.

Thulman, D.K. 2012. "Discriminating Paleoindian point types from Florida using landmark geometric morphometrics”. Journal of Archaeological Science 39: 1599-1607.

Torrence, R. 2006a. "Starch and archaeology". In Ancient Starch Research, edited by R. Torrence and H. Barton, 17-33. Walnut Creek, California: Left Coast Press.

Torrence, R. 2006b. "Description, classification and identification". In Ancient Starch Research, edited by R. Torrence and H. Barton, 115-143. Walnut Creek, California: Left Coast Press.

Torrence, R., Wright, R., and R. Conway, 2004. "Identification of starch granules using Classification using image analysis and multivariate techniques". Journal of Archaeological Science 31: 519-532.

Tweddle. J.C., K.J. Edwards, and N.R.J. Fieller. 2005. "Multivariate statistical and other approaches for the separation of cereal from wild Poaceae pollen using a large Holocene dataset". Vegetation History and Archaeobotany 14: 15-30.

Ucchesu, M., Orrù, M., Grillo, O. Venora, G., Paglietti, G., Ardu, A., and G. Bacchetta. 2016. "Predictive Method for Correct Identification of Archaeological Charred Grape Seeds: Support for Advances in Knowledge of Grape Domestication Process". PLoSOne 11: e0149814.

Ugent, D. S. 2006. "History of starch classification". In Ancient Starch Research, edited by R. Torrence and H. Barton, 116-118. Walnut Creek, California: Left Coast Press.

Ugent, D. S. Pozorski, and T. Pozorski. 1986. "Archaeological manioc (Manihot) from coastal of Peru". Economy Botany 40: 78-102. 
Valenzuela-Lamas,S., M. Baylac, T. Cucchi, and J.D. Vigne. 2011. "House mouse dispersal in Iron Age Spain: a geometric morphometrics appraisal". Biological Journal of the Linnean Society 102:483-497.

van Zeist, W., and J. Bakker-Heeres. 1985. "Archaeobotanical studies in the Levant 1. Neolithic sites in the Damascus basin: Aswad, Ghoraifé, Ramad". Palaeohistoria 24: 165256.

Vernet, J. L., E. Badal García, E. Grau Almero, and T. Ros Mora. 1987. "Charcoal analysis and the western mediterranean prehistoric flora". B.A.R., British Archaeological Reports International Series 299: 165-178.

Vrydaghs, L., T. Ball, H. Volkaert, I. Van den Houwe, J. Manwaring, and E. De Langhe. 2009. "Differentiating the volcaniform phytoliths of bananas: Musa acuminata". Ethnobotany Research and Applications 7: 239-246.

Wallace, M., Bonhomme, V., Russell, J., Stillman, E., George, T.S., Ramsay, L., Wishart, J., Timpany, S., Bull, H., Booth, A.. Martin, P. 2018. "Searching for the origins of bere barley: a geometric morphometric approach to cereal landrace recognition in archaeology". Journal of Archaeological Method and Theory. https://doi.org/10.1007/s10816-018-9402-2.

Wang, J., L. Liu, T.B. Ball, L. Yu, Y. Li, and F. Xing. 2016. "Revealing a 5,000-y-old beer recipe in China". Proceedings of the National Academy of Sciences 113 (23): 6444-6448.

Whittington G., and E. Edwards. 1989. "Problems in the interpretation of Cannabaceae pollen in the stratigtraphic record". Pollen et Spores 31: 79-96.

Whittington G., and A.D. Gordon. 1986. "The differentiation of the pollen of Cannabis sativa L. from that of Humulus lupulus L.”. Pollen et Spores 29: 111-120.

Wilczek, J., F. Monna, P. Barral, L. Burlet, C. Chateau, and N. Navarro. 2014. "Morphometrics of Second Iron Age ceramics - strengths, weaknesses, and comparison with traditional typology". Journal of Archaeological Science 50: 39-50.

Wilson, D.G. 1984. "The carbonisation of weed seeds and their representation in macrofossil assemblages". In Plants and Ancient Man: studies in palaeoethnobotany, edited by W. Van Zeist and W. Casparie, 201-206. Rotterdam: Balkema.

Wilson, J., K. Hardy, R. Allen, L. Copeland, R. Wrangham, and M. Collins 2010. "Automated classification of starch granules using supervised pattern recognition of morphological properties". Journal of Archaeological Science 37: 594-604.

Willcox, G. 2004. "Measuring grain size and identifying Near Eastern cereal domestication: evidence from the Euphrates valley." Journal of Archaeological Science 31(2): 145-150.

Zhang, J., H. Lu, N. Wu, X. Yang, and X. Diao. 2011. "Phytolith analysis for differentiating between Foxtail millet (Setaria italica) and Green Foxtail (Setaria viridis)". PLoS One 6 (5): e19726. 
Zhang, J., H. Lu, M., Liu, X., Diao, K., Shao, and N. Wu, 2018. "Phytolith analysis for differentiating between broomcorn millet (Panicum miliaceum) and its weed/feral type (Panicum ruderale)". Scientific reports 8 (1): 13022.

Zhao, Z., D.M. Pearsall, J.A.B. Benefer, and D.R. Piperno. 1998. "Distinguishing rice (Oryza sativa, Poaceae) from wild Oryza species through phytolith analysis, II: finalized method". Economic Botany 52: 134-135. 